\title{
ALTERNATIF MEDIA PEMBELAJARAN DENGAN LEARNING MANAGEMENT SYSTEM MOODLE PADA FAKULTAS TEKNOLOGI INFORMASI DAN KOMUNIKASI UNIVERSITAS SEMARANG
}

\author{
Vensy Vydia \\ Program Studi Sistem Informasi \\ Jurusan Teknologi \\ Informasi,Universitas Semarang \\ ester_vensy2004@yahoo.com
}

\author{
Nurtriana Hidayati \\ Program Studi Sistem Informasi \\ Jurusan Teknologi \\ Informasi,Universitas Semarang \\ anna@usm.ac.id
}

\author{
Nursanti Irliana \\ Program Studi Sistem Informasi \\ Jurusan Teknologi \\ Informasi,Universitas Semarang \\ santi@usm.ac.id
}

\begin{abstract}
Learning methods development in enducation world has grown rapidly in last few years. This rapid development becomes needs for the education in Indonesia. As the Information Techonolgy has been improved, the learning methods has to be improved also, using the concept of learning management system based on information technology. This concept then well known as e-Learning, bringing a kind of learning transformation. From convensional methods becomes digital, in contents also in the systems. In this case, there is an application to run eLearning, which is called Moodle. Moodle is one of Learning Management System tool which is usually used by education institutions. Moodle is open source software, can be relied to meet the users needs and supplies some additional moduls.

This research tried to apply Moodle as one of alternative learing model in Learning Based Competency Curriculum in the Faculty of Information Technology and Communication Universitas Semarang, especially Information System major. Try out has been done to four classes with two different lessons and some students as subject.

The result is e-Learning product using Moodle as a software package. As one of evaluation subject, questionaire has been distributed to students as a research subject.
\end{abstract}

Key words : e-learning, learning management system, moodle, web

\section{PENDAHULUAN}

Sistem pendidikan terdiri dari input, proses,output, dan outcome. Input terdiri dari mahasiswa, dosen, dan fasilitas. Proses terdiri dari kurikulum, kegiatan belajar mengajar, administrasi dan penilaian. Output terdiri lulusan dengan kompetensi tertentu, dan produk penelitian serta pengembangan. Outcome merupakan dampak lulusan dan produk perguruan tinggi terhadap lingkungan lokal, nasional, regional maupun internasional. Untuk Indonesia, Departemen Pendidikan Nasional menetapkan perguruan tinggi (PT) sebagai penghasil lulusan, Insan Indonesia yang cerdas, kompetitif dan berhati nurani. Sebagai outcome diharapkan lulusan perguruan tinggi mampu menyesuaikan diri terhadap kebutuhan para pemangku kepentingan di tingkat nasional maupun internasional.
Kurikulum berbasis kompetensi merupakan hasil pemikiran dalam rangka pembaharuan pendidikan yang selalu harus dilakukan dari waktu ke waktu. Pembaharuan pendidikan harus dilakukan karena berbagai perubahan yang terjadi di Indonesia yang disebabkan oleh situasi regional di Asia Tenggara dan di wilayah lainnya.

Kurikulum Nasional 1994 untuk PT merupakan kurikulum berbasis pada isi keilmuan. Kurikulum 1994 ini bertujuan untuk menghasilkan lulusan dengan kemampuan minimal dalam penguasaan pengetahuan, keterampilan, dan sikap sesuai sasaran kurikulum program studi. Penilaian terhadap peserta didik dilakukan oleh PT sendiri. Tuntutan terhadap PT adalah memenuhi kebutuhan masyarakat, industri, profesi dan perkembangan ilmu (scientific vision) untuk generasi masa depan memunculkan Kurikulum Berbasis Kompetensi (KBK) pada tahun 2000 yang mengintegrasikan 
kebudyaan dan 4 pilar pendidikan UNESCO. KBK ini diharapkan akan menghasilkan lulusan yang memiliki kompetensi tertentu sehingga dapat melakukan tindakan cerdas, penuh tanggungjawab sebagai syarat untuk dianggap mampu oleh masyarakat dalam melaksanakan tugas-tugas di bidang pekerjaan yang ditekuninya. KBK ini mengintegrasikan penilaian oleh masyarakat atau pemangku kepentingan (stakeholders) di samping penilaian oleh PT dan program studi sendiri.

Pendidikan berbasis kompetensi adalah suatu proses pendidikan yang dilakukan institusi, yang tidak lagi berfokus pada apa yang harus diajarkan oleh program studi tetapi berfokus pada apa yang harus dikuasai mahasiswa untuk dapat mengatasi berbagai keadaan yang kompleks pada dunia kerja. Pendidikan berbasis kompetensi berfokus pada hasil kompetensi yang berkaitan dengan apa yang diperlukan di dunia kerja, yang ditentukan oleh para pengguna lulusan maupun ikatan profesi yang terkait. Kompetensi yang dihasilkan juga makin rumit dan menuntut cara penilaian yang rumit pula, yaitu melibatkan portfolio, penilaian terhadap pengalaman kerja yang didapat pada saat magang, demonstrasi penguasaan kompetensi pada berbagai konteks yang relevan, pembelajaran yang melibatkan pendekatan bermain peran, penerapan berbagai standar yang biasa digunakan oleh profesi yang terkait.

Program Studi Sistem Informasi pada Fakultas Teknologi Informasi dan Komunikasi Universitas Semarang sejak semester Gasal 2014/2015 telah mencoba menerapkan Kurikulum Berbasis Kompetensi (KBK). Dimana salah satu konsep dalam kurikulum tersebut adalah mahasiswa mendapatkan pemahaman atas sebuah materi perkuliahan dengan menemukan sendiri, mecari sendiri dan belajar mandiri. Salah satu cara untuk mendukung sistem belajar mandiri ini dalah dengan adanya sebuah suplemen materi berbasis web, dimana mahasiswa dapat mengunggah materi sendiri dan mengerjakan tugas tugas mandiri di dalam web tersebut.

Berkaitan dengan hal tersebut, maka penulis mencoba untuk melakukan penelitian tentang manajemen pembelajaran KBK di program studi S1 Sistem Informasi dengan menggunakan perangkat lunak Moodle sebagai sarana untuk mendukung pembelajaran KBK di fakultas TIK.

Berdasarkan latar belakang di atas, perumusan masalah dalam penelitian ini adalah :

a. Bagaimana merekayasa software pembelajaran kuliah sehingga dapat digunakan oleh mahasiswamaupun dosen untuk menmabah pemahaman terhadap mata kuliah dan meningkatkan kualitas proses pembelajaran di kelas?. b. Bagaimana penerapan software pembelajaran ini di dalam kelas sehingga dapat meningkatkan kualitas proses pembelajaran berupa peningkatan antusias belajar mahasiswa, pemahaman mahasiswa dan pengalaman belajar mahasiswa terhadap mata kuliah yang menjadi obyek uji coba yang disampaikan dosen di kelas?.

Ketika LMS diimplementasikan di Fakultas TIK khususnya program studi S1 Sistem Informasi, seberapa besar penyerapan aplikasi tersebut bagi mahasiswa program studi S1 Sistem Informasi, khususnya dalam pembelajaran matakuliah yang dalam hal ini penulis batasi pada mata kuliah Metodologi Penelitian dan Struktur Data. Dimana Metodologi Penelitian terdiri dari dua kelas dan Struktur Data terdiri dari dua kelas.

\section{KAJIAN PUSTAKA}

\subsection{Konsep Learning Management System (LMS)}

Leaning Management System (LMS) merupakan aplikasi perangkat lunak untuk kegiatan online, program pembelajaran elektronik (e-learning program) dan konten pelatihan [2].

LMS harus memenuhi kriteria sebagai berikut :

1. Menggunakan layanan "self-service" dan "self-guided"

2. Mengumpulkan dan menyampaikan konten pembelajaran dengan cepat

3. Mengkonsilidasikan inisiatif pelatihan pada platform berbasis "web-scalable"

4. Mendukung portabilitas dan standar

5. Personalisasi isi dan memungkinkan penggunaan kembali pengetahuan

\subsection{Kurikulum Berbasis Koompetensi (KBK)}

Kurikulum memiliki makna yang beragam baik antar negara maupun antar institusi penyelenggara pendidikan. Hal ini disebabkan karena adanya interpretasi yang berbeda terhadap kurikulum,yaitu dapat dipandang sebagai suatu rencana (plan) yang dibuat oleh seseorang atau sebagai suatu kejadian atau pengaruh aktual dari suatu rangkaian peristiwa [3].

\subsection{Moodle}

Modular Object Oriented Dynamic Learning Environment (Moodle) merupakan perangkat lunak yang diproduksi untuk kegiatan belajar berbasis internet [6]. Moodle merupakan salah satu aplikasi dari konsep dan mekanisme belajar mengajar yang memanfaatkan teknologi informasi yang dikenal dengan konsep pembelajaran elektronik (e-learning). Moodle dapat digunakan secara bebas sebagai produk 
open source dibawah lisensi GNU. Moodle dapat diinstal di komputer dan sistem operasi apapun yang bisa menjalankan PHP dan mendukung database $S Q L$.

Di dunia e-learning, Moodle lebih dikenal fungsinya sebagai Course Management System atau Learning Management System (LMS). Dengan tampilan seperti halaman web pada umumnya, moodle memiliki fitur untuk menyajikan kursus (course), dimana pengajar dapat mengunggah materi ajar, soal dan tugas. Peserta didik pun dapat masuk log ke moodle kemudian memilih course yang disediakan atau di-enroll untuknya. Aktivitas peserta didik pun dalam moodle dapat terpantau progress dan nilainya.

\section{METODE PENELITIAN}

\subsection{Metode Penelitian Eksperimen (Metode Rekayasa)}

Penelitian eksperimen digunakan dalam rangka untuk merekayasa software pembelajaran berbasis kompetensi. Pendekatan dilakukan dengan menggunakan Model Prototype [9] sebagai berikut :

a. Identifikasi kebutuhan

Tahapan ini meliputi kegiatan mendifinisikan format seluruh sistem untuk menghasilkan software bantu, mengidentifikasikan seluruh kebutuhan, dan garis besar sistem yang akan dibuat. Kebutuhan yang akan diidentifikasi berupa perangkat lunak, perangkat keras, sumber daya manusia dan datadata yang dibutuhkan dalam sistem ini.

Dalam penelitian ini, kebutuhan sistem yang telah berhasil diidentifikasi adalah sebagai berikut:

1. Dibutuhkan sebuah sistem pembelajaran online untuk mendukung proses belajar mengajar pada Program Studi S1 Sistem Informasi .

2. Bahwa MOODLE tepat digunakan untuk membangun sistem ini dikarenakan MOODLE adalah free software, cukup sederhana dan lengkap fiturnya.

3. Perangkat keras telah tersedia baik di dalam Laboratorium Komputer, di Ruang Dosen, maupun laptop yang telah dimiliki oleh mahasiswa maupun dosen.

4. Sumber daya manusia yang terlibat adalah dosen pengampu mata kuliah, mahasiswa.

5. Data yang dibutuhkan antara lain yaitu :

a. Materi kuliah dari mata kuliah yang dijadikan obyek penelitian

b. Data dosen yang mengampu mata kuliah tersebut b. Perancangan sistem

Dalam tahap ini, dilakukan perancangan menggunakan teknik UML. Perancangan ini meliputi Use Case Diagram, Activity Diagram, Sequence Diagram dan Class Diagram.

c. Membangun prototyping

Tahapan ini meliputi kegiatan pembuatan rancangan sementara yang berfokus pada penyajian kepada pengguna software bantu. Contohnya adalah desain form input dan format output atau laporannya. Dengan konsep desain yang demikian diharapkan software bantu tersebut dapat direalisasikan sesuai kebutuhan pengguna.

Dalam penelitian ini, prototype dibangun dengan software MOODLE. Aplikasi ini terdiri dari:

$\begin{array}{ll}-\quad & \text { Materi kuliah } \\ - & \text { Soal latihan }\end{array}$

Sedangkan fiturnya terdiri dari :

- $\quad$ Pendaftaran dosen / pengampu

- $\quad$ Pendaftaran mahasiswa

- $\quad$ Download materi kuliah

- $\quad$ Menu untuk mengerjakan soal oleh mahasiswa

- Penilaian otomatis untuk soal soal pilihan

- $\quad$ Penilaian manual untuk soal essay

- Laporan nilai mahasiswa yang mengerjakan tugas atau soal

d. Evaluasi prototyping:

Tahap ini melibatkan pengguna. Dimana pengguna akan memberikan penilaian, apakah prototypenya sudah sesuai dengan kebutuhan dan keinginannya. Jika sudah , maka tahap selanjutnya akan dilaksanakan. Jika belum, maka akan diulang dari langkah a,b dan c.

Dalam penelitian ini, pengguna yang dilibatkan adalah pengelola Program Studi S1 Sistem informasi dan perwakilan mahasiswa yang mengikuti mata kuliah yang dijadikan obyek.

e. Menguji Sistem dan Evaluasi

Tahap ini merupalan tahap uji coba pada sistem. Dan diamati apakah sudah sesuai dan sudah dapat mengatasi kebutuhan serta kendala lapangan. Uij coba ini menjadi evaluasi bersama antara pengguna dan pembuat sistem. Jika dirasa masih ada yang kurang sesuai, maka akan diulang dari langkah b ke d. Jika sudah cocok, dilanjutkan dengan tahap ke $\mathrm{f}$. 
Dalam penelitian ini, dilakukan uji coba terhadap dua kelas mata kuliah. Yaitu mata kuliah Interaksi Manusia dan Komputer, dan Mata Kuliah Metodologi Penelitian. Dengan jumlah mahasiswa sebagai sampel adalah 25 orang per kelas.

Pengujian sistem dilaksanakan di dalam kelas dan di luar kelas masing - masing dengan mengakses portal yang dimaksud, oleh mahasiswan dan dosen pengampu. Dosen mencoba mengunggah materi dan soal. Kemudian mahasiswa mendownload materi tersebut dan mencoba mengerjakan soal latihan yang telah disiapkan. Selanjutnya, dosen mngkoreksi dan memberikan nilai atas pekerjaan mahasiswa. Dosen juga mengakses laporan nilai mahasiswa atas tugas yang telah dikerjakan.

f. Implementasi Sistem

Software bantu yang sudah jadi dan diterima oleh pengguna, siap diimplementasikan.

Dalam penelitian ini, implementasi penuh belum dilakukan, karena terkait dengan kebijakan dan prosedur fakultas.

\subsection{Metode Penelitian Tindakan Kelas (Class Action Research)}

Pendekatan penelitian tindakan kelas digunakan dalam rangka untuk menguji dampak penggunaan software aplikasi pembelajaran bebasis kompetensi. Tindakan kelas yang dimaksud dalam penelitian ini adalah proses pembelajaran mata kuliah di kelas dilakukan dengan bantuanware software aplikasi media pembelajaran menggunakan MOODLE.

\section{a. Populasi dan Sampel Penelitian \\ Populasi}

Prototipe yang dibuat pada aplikasi pembelajaran ini adalah terdiri dari :

- Materi Mata Kuliah Struktur Datadan Mata Kuliah Metodologi Penelitian, masing - masing terdiri dari satu pokok bahasan sesuai Kurikulum Berbasis Kompetensi pada Program Studi S1 Sistem Informasi, yang diupload pada aplikasi MOODLE. Softwareaplikasi tersebut akan dimanfaatkan oleh dosen untuk membantu penyampaianmateri ajar kepada Mahasiswa . Sehingga populasi penelitian untuk tindakan kelas ini adalah dosen Mata Kuliah Interaksi Manusia dan Komputer dan dosen Mata Kuliah Metodologi
Penelitian dari kelas yang telah ditunjuk sebagai subyek pengguna aplikasi ini dan mahasiswa yang mengikuti mata kuliah tersebut dengan jumlah tertentu sebagai obyek penggunaan aplikasi (penerima bahan ajar).

- Soal latihan sebagai tugas mahasiswa dan bahan evaluasi pembanding, sebelum dan sesudah menggunakan aplikasi ini.

Batasan populasi untuk penelitian ini adalah mahasiswa program studi S1 Sistem Informasi yang mengikuti perkuliahan Metodologi Penelitian dan Struktur Data Semester Genap 2014/20015, dengan jumlah 40 mahasiswa.

Sampel

Mengingat keterbatasan sumber daya (biaya, tenaga dan waktu) maka dari populasi tersebut kemudian akan dipilih sampel penelitian menggunakan teknik Purposive Sampling[10] , dengan terminologi pemilihan sampel sebagai berikut :

- Karakteristik dosen pengajar diasumsikan sesuai ditinjau dari aspek kemampuan atau kompetensi mengajar mata kuliah yang dimaksud.

- Karakteristik populasi mahasiswa diasumsikan homogen ditinjau dari aspek materi ajar yang harus diterima dari dosen sesuai kurikulum yang berlaku di fakultas

- Dari populasi yang sudah ditentukan, mula-mula dipilih kelas sampel sebanyak 4 kelas, yaitu :

- Kelas Struktur Data, dosen pengampu Nurtriana Hidayati,M.Kom, dengan jadwal Hari Kamis, Pukul 08.00 Ruang E.1.1, jumlah mahasiswa 32 orang, diambil sampel 10 orang.

- Kelas Struktur Data, dosen pengampu Nursanti Irliana, M.Kom, dengan jadwal Hari SelasaPukul $08.00 \quad$ Ruang E.1.1, jumlah mahasiswa 32 orang, diambil sampel 10 orang. 
- Kelas Metodologi Penelitian, dosen pengampu Nurtriana Hidayati,M.Komdengan jadwal Hari Jumat, Pukul 18.15 Ruang Q1.2, jumlah mahasiswa 62 orang, diambil sampel 10 orang.

- Kelas Metodologi Penelitian, dosen pengampu Vensy Vydia, M.Komdengan jadwal Hari Kamis, Pukul 18.15 Ruang q.1.1, jumlah mahasiswa 50 orang, diambil sampel 10 orang.

Penentuan jumlah 4 kelas sebagai sampel ini dilakukan secara purposive sampling, dimana ke-4kelas tersebut saat penelitian ini tengah dilaksanakan, merupakan kelas yang diampu oleh para peneliti sehingga akan terjadi efektifitas kegiatan/penelitian.

Dari ke-4kelas yang dipilih sebagai kelas sampel, kemudian dipilih masing-masing sebanyak 10 mahasiswa, atau total sebanyak 40 mahasiswa. Dengan demikian diperoleh dosen sampel sebanyak 3 orang dosen untuk 4 kelas dan mahasiswa sampel sebanyak 40 mahasiswa.

\section{HASIL DAN PEMBAHASAN}

\subsection{ANALISIS SISTEM}

\subsubsection{ANALISIS MATERI}

Analisis materi merupakan kegiatan mengidentifikasi materi yang akan dijadikan sampel dan diupload ke dalam software aplikasi pembelajaran ini. Jadi analisis materi yang dimaksudkan disini adalah untuk mengidentifikasi materi ajar yang akan dirancang dalam media pembelajaran. Materi ajar dalam penelitian ini adalah :

1. Mata Kuliah Struktur Data, dengan sub bab Sorting.

Standar kompetensi : Mahasiswa mengerti teknik - teknik sorting array dan mampu mengerjakan soal-soal sorting dengan baik.

2. Mata Kuliah Metodologi Penelitian, dengan sub bab Metodologi Penelitian Teknologi Informasi.

Standar Kompetensi :Mahasiswa memahami bagaimana bentuk penelitian dalam bidang Teknologi Informasi.
Analisis kebutuhan merupakan kegiatan untuk menganalisis berbagai kebutuhan yang terkait dengan pengembangan perangkat lunak komputasi matematika, meliputi kebutuhan software dan kebutuhan hardware.

\section{A. Kebutuhan Software}

Software yang akan dikembangkan software aplikasi pembelajaran yang dibuat menggunakan program MOODLE. MOODLEmerupakan software yang dapat bekerja di bawah sistem operasi windows maupun linux atau macintosh. Dalam penelitian ini digunakan sistem operasi Windows 7 Ultimate.

\section{B. Kebutuhan Hardware}

Perangkat keras yang diperlukan untuk instalasi program ini minimal komputer dengan prosesor Intel Core, RAM 2,4 GHz (disarankan di atasnya), dan Hardisk : 500 GB MB. Bagi pengguna sistem operasi yang lain (UNIX atau macintosh) dapat menyesuaikan spesifikasi yang disarankan pada petunjuk instalasi.

\subsubsection{UNIFIED MODELLING LANGUAGE $(\mathrm{UML})$}

\subsubsection{USE CASE}

Use case dari sistem ini adalah sebagai berikut :

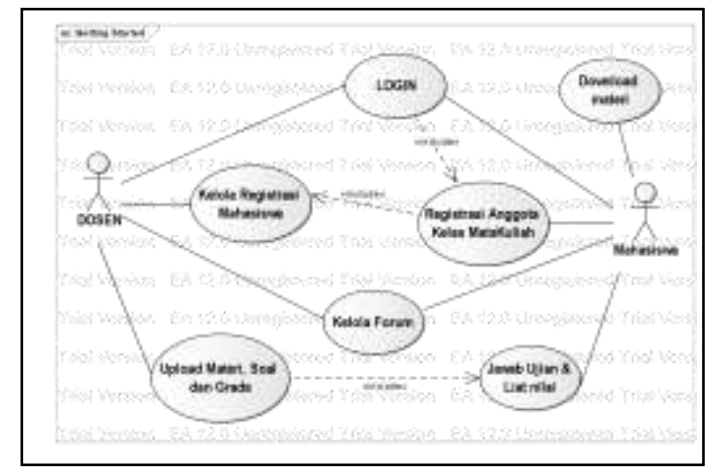

Gambar 4.1 Use Case Learning Management System dengan MOODLE

\subsubsection{ANALISIS KEBUTUHAN}


Desain Menu Utama dalam sistem ini adalah sebagai berikut :

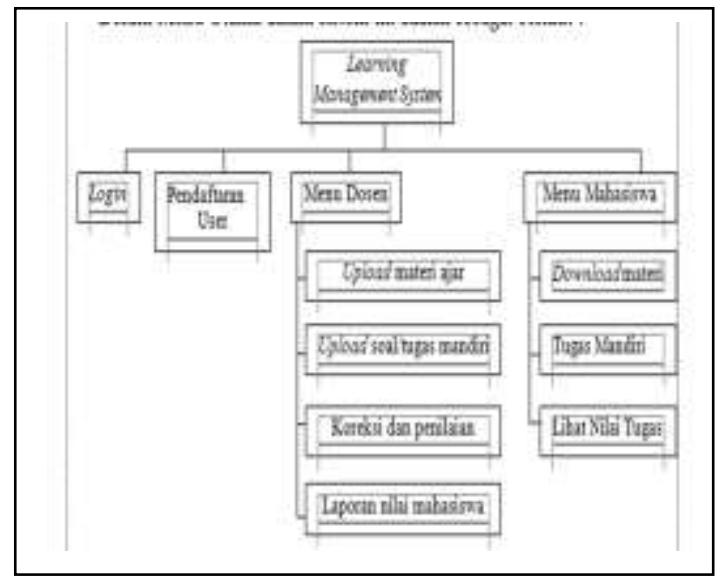

Gambar 4.2 Desain Menu Utama Learning Management System Dengan MOODLE

\subsubsection{IMPLEMENTASI SISTEM}

Alur implementasi sistem ini secara ringkas dapat dilihat dari bagan berikut ini :

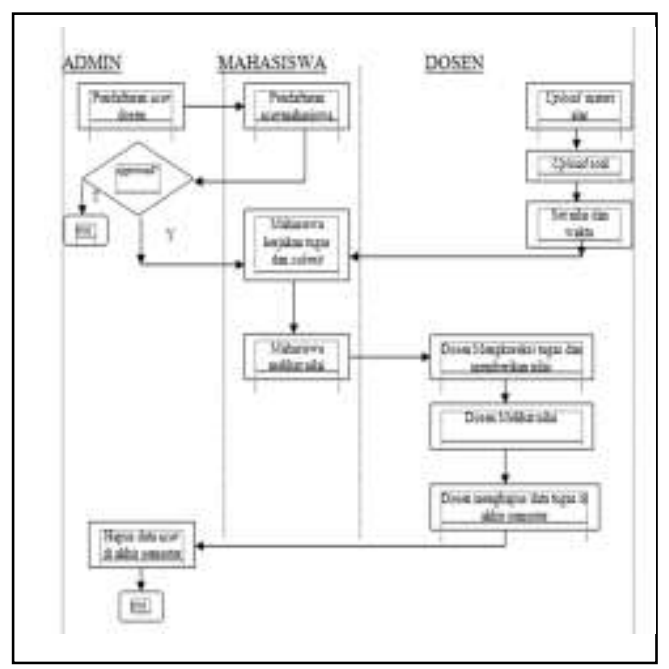

Gambar 4.3 : Ringkasan Alur Implementasi Sistem
Struktur Data dan kelas Metodologi Penelitian. Dimana kelas Struktur Data diambil 2 kelas dan Metodologi Penelitian diambil 2 kelas. Kelas pertama adalah kelas tanpa tindakan (tanpa menggunakan software aplikasi pembelajaran), dan kelas kedua dengan tindakan (dengan menggunakan software aplikasi pembelajaran ).

Tes yang dilakukan dalam penelitian ini adalah sebagai berikut :

1. Pretest kelas I , adalah setelah menerima materi ajar tanpa tindakan.

2. Postest kelas I, adalah setelah menerima materi ajar dengan tindakan.

3. Pretest kelas II, adalah setelah menerima materi ajar dengan tindakan.

Kelas II tidak diadakan postest karena jumlah tatap muka hanya satu kali dan langsung menggunakan software aplikasi pembelajaran.

Setiap kelas, jumlah mahasiswa sebagai sampel adalah 10 orang.

Hasil pretest dan postest kelas I dan kelas II Materi Struktur Data adalah sebagai berikut :

Tabel 4.1 Pretestdan Postest Kelas I Materi Struktur Data

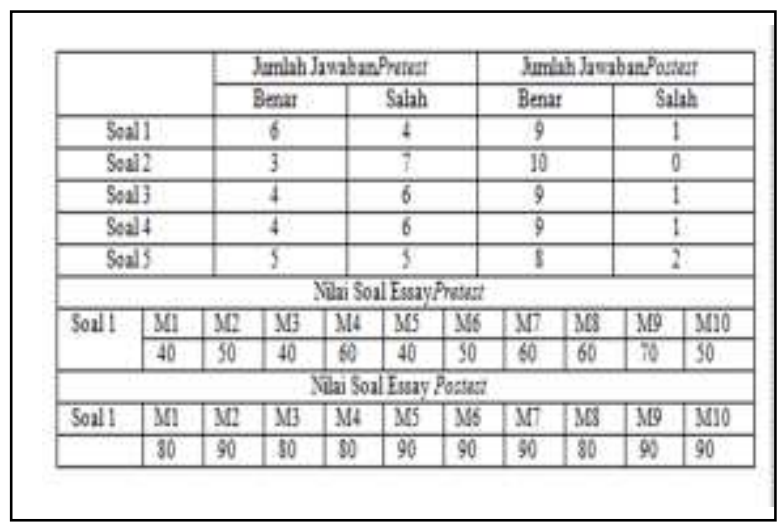

Tabel 4.2 Perbandingan Hasil Nilai Soal Essay Kelas I Materi Struktur Data

\begin{tabular}{|c|c|}
\hline & $\begin{array}{c}\text { Rata-rata } \\
\text { Nilai Essay }\end{array}$ \\
\hline Nilai Pretest & 52 \\
\hline Nilai Postest & 86 \\
\hline
\end{tabular}

\subsubsection{ANALISIS DESKRIPSI \\ 4.3.2.1 ANALISIS HASIL PRETEST DAN POSTEST MAHASISWA}

Penelitian ini dilakukan pada kelas 
Tabel 4.3 Pretest Kelas I Materi Stuktur Data dibandingkan dengan Pretest Kelas II Materi Struktur Data

\begin{tabular}{|c|c|c|c|c|}
\hline & \multicolumn{2}{|c|}{ Imbahlantba Kckss! } & \multicolumn{2}{|c|}{ 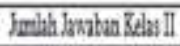 } \\
\hline & $\operatorname{Ben} 2$ & Salh & Beat & Sath \\
\hline Sod! & 6 & 4 & 9 & 1 \\
\hline Sol? & 3 & 7 & 8 & $?$ \\
\hline Soli & 4 & 6 & 9 & I \\
\hline Sol! & i & 6 & 9 & I \\
\hline Sod 5 & 5 & 5 & 10 & $\pi$ \\
\hline \multicolumn{5}{|c|}{ Rath-ntakainatay } \\
\hline \multicolumn{3}{|c|}{ Kàs! } & \multicolumn{2}{|c|}{5} \\
\hline \multicolumn{3}{|c|}{ BaslI } & \multicolumn{2}{|c|}{8} \\
\hline
\end{tabular}

Hasil pretest dan postest kelas I dan kelas II Materi Metodologi Penelitian adalah sebagai berikut :

Tabel 4.4 Pretest dan Postest Kelas I Materi Metodologi Penelitian

\begin{tabular}{|c|c|c|c|c|c|c|c|c|c|c|}
\hline & & \multicolumn{5}{|c|}{ Jariah Jaraban F̂tét } & \multicolumn{4}{|c|}{ Junlah janaban Poutest } \\
\hline & & \multicolumn{3}{|c|}{ BenaI } & \multicolumn{2}{|l|}{ Salah } & \multicolumn{2}{|c|}{ BenaI } & \multicolumn{2}{|c|}{ Salah } \\
\hline \multicolumn{2}{|c|}{ Soall } & & 5 & & \multicolumn{2}{|l|}{5} & \multicolumn{2}{|l|}{9} & \multicolumn{2}{|c|}{1} \\
\hline \multicolumn{2}{|c|}{ Soal2 } & & 4 & & \multicolumn{2}{|l|}{6} & \multicolumn{2}{|l|}{10} & \multicolumn{2}{|c|}{0} \\
\hline \multicolumn{2}{|c|}{ Soal3 } & & 6 & & \multicolumn{2}{|l|}{4} & \multicolumn{2}{|l|}{9} & \multicolumn{2}{|c|}{ I } \\
\hline \multicolumn{2}{|c|}{ Soal4 } & & 5 & & \multicolumn{2}{|l|}{5} & \multicolumn{2}{|l|}{9} & \multicolumn{2}{|c|}{1} \\
\hline \multicolumn{2}{|c|}{ Soal5 } & & 6 & & \multicolumn{2}{|l|}{4} & \multicolumn{2}{|l|}{8} & \multicolumn{2}{|c|}{2} \\
\hline \multicolumn{11}{|c|}{ Whi Soal Eragy Fontust } \\
\hline \multirow[t]{2}{*}{ Soall } & MI & MI & M3 & MA & MS & M6 & X7 & M8 & D9 & MIO \\
\hline & 40 & 50 & 40 & 30 & 40 & 40 & 30 & 40 & 40 & 50 \\
\hline \multicolumn{11}{|c|}{ Nhai Soal Essay Postest } \\
\hline \multirow[t]{2}{*}{ Soall } & MI & $\mathrm{ML}$ & M3 & MA & M5 & M6 & $\mathrm{MT}$ & MA8 & 19 & MIO \\
\hline & 90 & 80 & 90 & 90 & 90 & 90 & 90 & 90 & 80 & 90 \\
\hline
\end{tabular}

Tabel 4.5 Perbandingan Hasil Nilai Soal Essay Kelas I

\begin{tabular}{|c|c|}
\hline $\begin{array}{c}\text { Materi Metodologi } \\
\text { Penelitian }\end{array}$ & $\begin{array}{c}\text { Rata-rata } \\
\text { Nilai Essay }\end{array}$ \\
\hline Nilai Pretest & 40 \\
\hline Nilai Postest & 88 \\
\hline
\end{tabular}

Tabel 4.6 Pretest Kelas I Materi Metodologi Penelitian dibandingkan dengan Pretest Kelas II Materi Metodologi Penelitian

\begin{tabular}{|c|c|c|c|c|}
\hline & \multicolumn{2}{|c|}{ 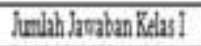 } & \multicolumn{2}{|c|}{ Imbhlavaban Reas II } \\
\hline & Benat & Salah & Berat & Salah \\
\hline Soall & 5 & 5 & 9 & $T$ \\
\hline Scal? & ! & 6 & 9 & $T$ \\
\hline Sod? & 6 & 4 & 8 & $?$ \\
\hline Sold & 5 & 3 & 10 & 0 \\
\hline Scals & 6 & 4 & 10 & 0 \\
\hline \multicolumn{5}{|c|}{ Rata-nalabitsuy } \\
\hline \multicolumn{3}{|c|}{ Resat } & \multicolumn{2}{|c|}{ 40 } \\
\hline \multicolumn{3}{|c|}{ Retas II } & \multicolumn{2}{|c|}{8} \\
\hline
\end{tabular}

\subsubsection{ANALISIS HASIL KUESIONER}

Kuesioner diberikan kepada 40 responden yang terdiri dari 10 mahasiswa per kelas. Kuesioner ini terdiri dari 2 (dua) aspek yaitu aspek antusias belajar dan aspek pengalaman belajar. Bentuk dan isi kuesioner terdapat pada Lampiran 2. Hasil rekapitulasi kuesioner adalah sebagai berikut :

Tabel 4.7 Rekapitulasi Kuesioner

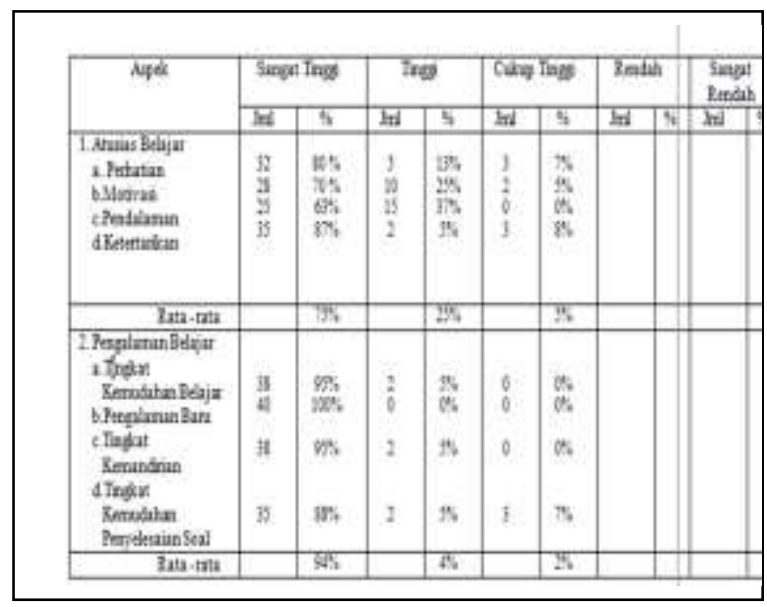

Berdasarkan respon antusias belajar, rata rata $75 \%$ mahasiswa responden menyatakan bahwa dengan software aplikasi pembelajaran ini, mereka lebih merasa tertarik, mudah mendalami, termotivasi dan lebih memperhatikan kuliah yang diberikan oleh dosen. 
Berdasarkan respon pengalaman belajar, rata-rata $94 \%$ mahasiswa responden menyatakan mendapatkan pengalaman baru, lebih mandiri dan merasa lebih mudah menyelesaikan soal-soal

\section{SIMPULAN DAN SARAN}

\subsection{SIMPULAN}

Dari penelitian yang telah dilakukan, dapat diambil kesimpulan sebagai berikut :

1. Bahwa software aplikasi pembelajaran dengan menggunakan MOODLE ini dapat digunakan sebagai alternatif pembelajaran dengan Kurikulum Berbasis Kompetensi pada Program Studi S1 Sistem Infomasi Universitas Semarang.

2.Terdapat perbedaan respon mahasiswa antara kelas yang menggunakan tindakan dan yang tidak menggunakan tindakan. Dimana terbukti bahwa penggunaan tindakan membantu pemahaman dan penyerapan materi oleh mahasiswa.

3. Dari hasil kuesioner mahasiswa disimpulkan bahwa mahasiswa cukup antusias dan merasa terbantu oleh software aplikasi ini.

\subsection{SARAN}

Saran yang dapat diberikan apabila ada kelanjutan implementasi dan pengembangan software aplikasi ini adalah sebagai berikut :

1. Akan lebih baik jika software aplikasi ini dapat berkorelasi dengan sistem informasi terpadu untuk penilaian mahasiswa. Sehingga dosen bahwa dengan software aplikasi pembelajaran ini, mereka lebih merasa lebih mudah belajar, tidak lagi melakukan rekap manual atas nilai.

2. Jika hendak dilakukan implementasi atas sistem ini, sebaiknya dilakukan pelatihan diluar semester yang akan diuji cobakan. Sehingga tidak terjadi penundaan implementasi akibat ketidakmengertian dosen dan mahasiswa.

\section{DAFTAR PUSTAKA}

Azwar, S 2004. Reliabilitas dan Validitas. Yogyakarta : Pustaka Pelajar Offset.

Cole, Foster. 2008. Using Moodle "Teaching With The Popular Open Source Course Management System". $2^{\text {nd }}$ Ed. USA: O’Reilly Community Press.

Ditjen DIKTI. 2008. Buku Panduan Pengembangan Kurikulum Berbasis Kompetensi Pendidikan Tinggi (Sebuah Alternatif Penyusunan Kurikulum). Jakarta: Sub Direktorat Kurikulum dan Program Studi. Direktorat Akademik DIKTI.

Sugiyono. 2010. Metode Penelitian Kuantitatif, Kualitatif dan R \& D. Bandung: Alfabeta

Suharto, Ignatius. 2004. Perekayasaan Metodologi Penelitian. Ed. I. Yogyakarta: Andi. 